\title{
Sammenligning av to blodprøver fra samme person analysert ved to laboratorier
}

\author{
A. Tverdal ${ }^{1}$, A. Åsberg ${ }^{2}$, K.H. Bønaa ${ }^{3}$, I. Stensvold ${ }^{1}$, G. Grudt ${ }^{2}$, O.C. Ingebretsen ${ }^{3}$ og P. Urdal ${ }^{4}$ \\ ${ }^{I}$ Statens helseundersøkelser \\ ${ }^{2}$ Innherred sykehus \\ ${ }^{3}$ Universitetet $i$ Tromsø \\ ${ }^{4}$ Ullevål sykehus
}

\section{INNLEDNING}

Epidemiologiske undersøkelser av lipidnivået hos befolkningen er helt avhengig av at analysemetodene holder stabilt nivå over flere år. Dette er lettest å oppnå hvis man hele tiden benytter ett laboratorium, og hjerte-karundersøkelsene til Statens helseundersøkelser har konsekvent benyttet Klinisk kjemisk avdeling, Ullevål sykehus. Ulike hensyn kan likevel tilsi at andre laboratorier benyttes. Undersøkelsene til Universitetet i Tromsø som har har vært gjennomført fire ganger i perioden 1973-1995, har vært utført ved Klinisk kjemisk avdeling, Regionsykehuset i Tromsø. Helseundersøkelsen i Nord-Trøndelag 1995-1997 har benyttet Sentrallaboratoriet, Innherred sykehus. I dette arbeidet viser vi hvor store forskjellene blir hvis feltlagene sender prøver fra samme person til ulike laboratorier. Vi har undersøkt forskjellene mellom Regionsykehuset i Tromsø og Ullevål sykehus, og mellom Innherred sykehus og Ullevål sykehus.

\section{MATERIALE OG METODE}

I forbindelse med undersøkelsen i Tromsø 1994/95 ble det for 988 menn og 1105 kvinner i alder 40-42 år tappet to glass med blod. Ett glass ble sendt til Ullevål og ett til Universitetet i Tromsø. Tilsvarende ble gjort i forbindelse med undersøkelsen i Nord-Trøndelag i 1996 for 475 menn og 553 kvinner.

Blodprøvene ble sentrifugert innen to timer etter tapping. De ble så lagt i kjølecontainere og levert på postkontoret samme ettermiddag/kveld for postsending til laboratoriene. Ved ankomst til laboratoriene ble prøvene oppbevart kjølig til de ble analysert. Dette skjedde innen 3 dager etter ankomst til laboratoriet.

Totalkolesterol, triglyserider og glukose ble analysert med standard kalibratorer og enzymatisk metode. Essensielt de samme metoder og samme analyseutstyr ble brukt på de tre laboratorier. HDL kolesterol ble også målt med standardmetodikk som for kolesterol, etter felling av de andre lipoproteiner.

Gjennomsnitt og standarddeviasjon for differansen mellom to laboratorier, samt andelen som har serumverdi over en angitt grense, blir gitt. Differansen er definert som Ullevål minus Tromsø, alternativt Ullevål minus Innherred. Punktplot er tegnet for hver sammenligning og korrelasjonskoeffisienten er gitt. Videre er gjennomsnittet for hvert par plottet mot differansen (Y-aksen). Denne gir forskjellen mellom laboratoriene etter nivå, uavhengig av den effekten som skyldes regresjon mot middelverdien.

\section{RESULTATER}

\section{Ullevål mot Tromsø:}

Gjennomsnittet for kolesterol er $0,181 \mathrm{mmol} / \mathrm{l}$, eller $3,2 \%$ høyere i Tromsø enn på Ullevål (tabell 1). Gjennomsnittet for triglyserider er derimot $0,121 \mathrm{mmol} / \mathrm{l}$, eller 7,4\% lavere i Tromsø.

Andelen med kolesterol lik eller større enn 8 $\mathrm{mmol} / \mathrm{l}$ er høyere i Troms $\varnothing$, mens andelen med triglyserider lik eller større enn $3 \mathrm{mmol} / \mathrm{l}$ er lavere (tabell 2). Forskjellene er henholdsvis 1,15 og 1,00 prosentpoeng, eller 53,5 og 10,1 prosent.

Det høyere kolesterolnivået i Tromsø er noe mer uttalt ved høyere nivå av kolesterol (figur 1, øvre del). Punktene er imidlertid godt samlet rundt diagonalen med ett unntak; en verdi er 47,6 prosent lavere i Tromsø. Triglyseridverdien i samme serum er kun 5,8 prosent lavere i Tromsø.

Også for triglyserider er det god overensstemmelse mellom de to laboratorier (figur 1, nedre del). Imidlertid pekes det på ett punkt som ligger et stykke fra diagonalen hvor forskjellen er 22,1 prosent. Kolesterolforskjellen i samme serum var imidlertid ikke påfallende; 4,5 prosent.

\section{Ullevål mot Innherred:}

Det bemerkes at for total- og HDL-kolesterol har Innherred bestemt verdiene med ett siffer etter desimal, mens Ullevål har bestemt verdiene med to siffer.

Innherred ligger 1,2 prosent høyere i gjennomsnitt for kolesterol enn Ullevål, mens triglyseridnivået er 8,5 prosent lavere (tabell 1). Nivået av HDL-kolesterol og glukose er også lavere i Innherred, henholdsvis 1,1 og 3,5 prosent.

Det er gjort kjøringer hvor verdiene for total- og HDL-kolesterol fra Ullevål er gjort om slik at det kun er ett desimalsiffer. Differansen, Ullevål minus 
Tabell 1. Serum fra samme person analysert ved to laboratorier. Gjennomsnitt og standarddeviasjon.

\begin{tabular}{|c|c|c|c|c|c|c|}
\hline \multirow{2}{*}{$\begin{array}{l}\mathrm{n}=2093 \\
\mathrm{mmol} / \mathrm{l}\end{array}$} & \multicolumn{2}{|c|}{ Ullevål } & \multicolumn{2}{|c|}{ Tromsø } & \multicolumn{2}{|c|}{$\begin{array}{l}\text { Ullevål minus } \\
\text { Troms }\end{array}$} \\
\hline & Gj.snitt & St.dev. & Gj.snitt & St.dev. & Gj.snitt & St.dev. \\
\hline Kolesterol $^{1}$ & 5,64 & 1,07 & 5,82 & 1,10 & $-0,181$ & 0,228 \\
\hline Triglyserider & 1,64 & 1,17 & 1,52 & 1,12 & 0,121 & 0,152 \\
\hline $\mathrm{n}=1028$ & U1l & evål & Innh & erred & $\begin{array}{l}\text { Ulleve̊ } \\
\text { Innl }\end{array}$ & $\begin{array}{l}1 \text { minus } \\
\text { erred }\end{array}$ \\
\hline Kolesterol & 5,61 & 1,06 & 5,68 & 1,09 & $-0,068$ & 0,192 \\
\hline Triglyserider & 1,83 & 1,34 & 1,68 & 1,25 & 0,155 & 0,226 \\
\hline HDL-kolesterol $^{2}$ & 1,37 & 0,32 & 1,36 & 0,36 & 0,015 & 0,195 \\
\hline Glukose $^{3}$ & 5,45 & 1,11 & 5,26 & 1,06 & 0,190 & 0,349 \\
\hline
\end{tabular}

${ }^{1} \mathrm{n}=2092 \quad{ }^{2} \mathrm{n}=1022 \quad{ }^{3} \mathrm{n}=1024$

Tabell 2. Serum fra samme person analysert ved to laboratorier. Andel (\%) over en gitt grense.

\begin{tabular}{|c|c|c|c|c|}
\hline \multirow[b]{2}{*}{$\mathrm{mmol} / \mathrm{l}$} & Ullevål & Tromsø & Ullevål & Innherred \\
\hline & \multicolumn{2}{|c|}{$\%$ over grense $(n=2092)$} & \multicolumn{2}{|c|}{$\%$ over grense $(\mathrm{n}=1028)$} \\
\hline Kolesterol $(\geq 8)$ & 2,15 & 3,30 & 2,14 & 3,31 \\
\hline Triglyserider $(\geq 3)$ & 9,89 & 8,89 & 12,06 & 10,02 \\
\hline HDL-kolesterol $(\geq 2)^{1}$ & & & 2,05 & 6,91 \\
\hline Glukose $(\geq 8)^{2}$ & & & 2,73 & 1,95 \\
\hline
\end{tabular}

${ }^{1} \mathrm{n}=1022 \quad{ }^{2} \mathrm{n}=1024$

Figur 1. Kolesterol og triglyserider analysert ved hhv. Klinisk kjemisk avdeling, Ullevål sykehus, og Klinisk kjemisk avdeling, Regionsykehuset i Tromsø.

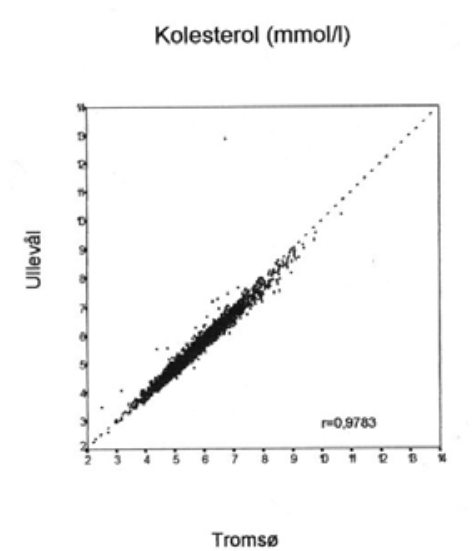

Tromsø

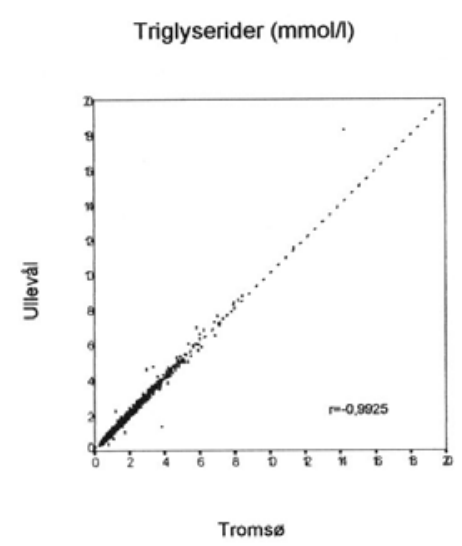

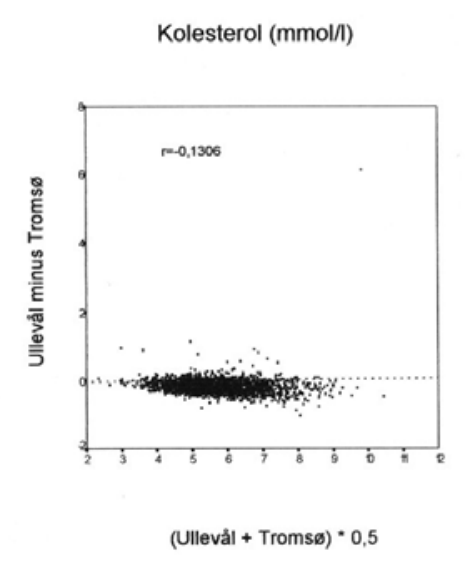

Triglyserider $(\mathrm{mmol} / \mathrm{l})$

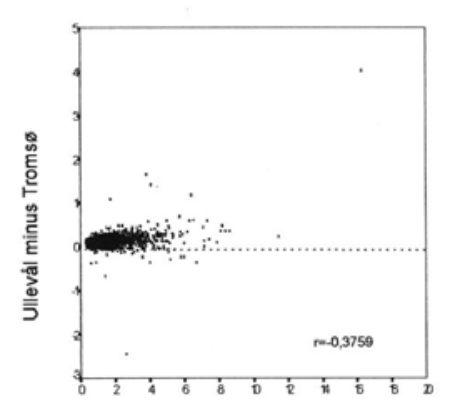

(Ullevål + Tromsø) $\cdot 0,5$ 
Innherred, ble $-0,064$ og $0,020 \mathrm{mmol} / 1$ for henholdsvis total- og HDL-kolesterol når det ble benyttet vanlig forhøyning, og $-0,112 \mathrm{og}-0,032 \mathrm{mmol} / 1$ når det ble benyttet trunkering.

Forskjell i prevalens av høye verdier er mest uttalt for HDL-kolesterol (tabell 2). Andelen med verdi lik eller større enn $2 \mathrm{mmol} / \mathrm{l}$ er 4,86 prosentpoeng, eller 237,1 prosent høyere ved Innherred. For kolesterol, triglyserider og glukose var de tilsvarende tall 1,17 prosentpoeng (54,7 prosent) høyere, 2,04 prosentpoeng (16,9 prosent) lavere og 0,78 prosentpoeng $(28,6$ prosent) lavere ved Innherred.

Forskjell i antall desimalsiffer framgår tydelig av plottene (figur 2 og 3, øvre del). Det uoverensstemmende kolesterolpunktet (38 prosent høyere på Innherred) ga mindre avvikende bestemmelser ved de to laboratorier for de andre parametrene, med den største forskjellen for HDL-kolesterol (16,9 prosent høyere på Innherred). Det lavere nivået for triglyserider og HDLkolesterol ved Innherred er mest uttalt når verdiene ligger lavt (figur 2, nedre del og figur 3, øvre del). For HDL-kolesterol synes nivået mellom laboratoriene å snu; ved nivåer over $2 \mathrm{mmol} / \mathrm{l}$ gir analyse ved Innherred høyere verdi enn ved Ullevål.

\section{DISKUSJON}

To laboratorier som analyserte på serum fra samme person kom ut med noe forskjellig gjennomsnittsnivå. Forskjellene varierte mellom 1,1 og 8,5 prosent. Forskjellen i prevalens av høye nivåer var prosentvis større; mellom 10,1 og 237,1 prosent.

Vi vet ikke hvorfor de observerte forskjeller har oppstått. Ulikheter både i kalibrering og metode kan spille inn. Ullevål har en triglyseridmetode som korrigerer for fritt glyserol i prøven. Dermed ville vi forvente at Ullevål målte lavere triglyseridverdier enn Innherred, men det omvendte har faktisk funnet sted. HDL-bestemmelsene innebærer manuelle rutiner med felling av prøvematerialet, slik at vi her må vente større ulikheter mellom laboratoriene enn for de andre analysene.

Totalkolesterol er en sentral prediktor for hjerteinfarkt. For å sette kolesterolforskjellen mellom Ullevål og Tromsø inn i en annen sammenheng, nevnes at forskjellen tilsvarer en forskjell i dødelighet på 7 prosent (1).

Et spørsmål som nå vil reise seg er hvilke grep som bør gjøres for å kunne foreta en mest mulig valid

Figur 2. Kolesterol og triglyserider analysert ved hhv. Klinisk kjemisk avdeling, Ullevål sykehus, og Sentrallaboratoriet, Innherred sykehus.
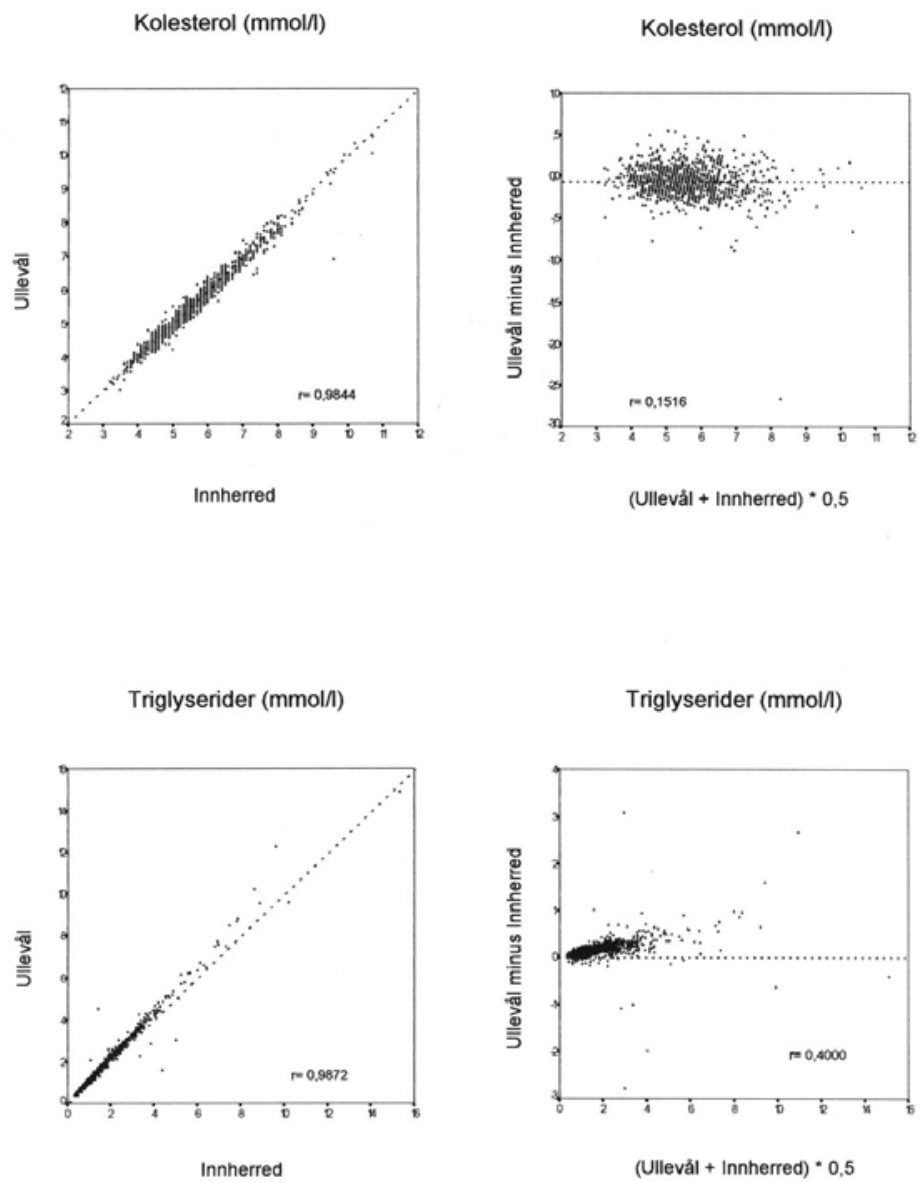
sammenligning mellom f.eks. denne Nord-Trøndelagsundersøkelsen (hunt) (serumbestemmelser på Innherred) og den som ble gjennomført i 1989 (serumbestemmelser på Ullevål). Et valg er å benytte verdiene som de er og så gjøre vurderingene i lys av resultatene i denne studien. En annen mulighet er å transformere verdiene i hunt ved hjelp av en regresjonsligning. I og med at det ikke er gjort replikatanalyser i samme serum har vi valgt ikke å presentere regresjonsligninger. Disse er det imidlertid mulig å beregne ut fra de resultater som er gitt. Vi tror det første valget vil være enklest å formidle.

Et annet spørsmål er om tverrsnittsammenhengene som f.eks. mellom vekt og triglyserider, blir forskjellig når triglyseridverdien, bestemt ved to laboratorier, benyttes. Vi beregnet korrelasjonskoeffisienter mellom de fire serumvariable som inngikk i sammenligningen
Ullevål-Innherred, og også mellom disse fire variable og vekt og systolisk blodtrykk (data ikke vist). Konklusjonen var at korrelasjonskoeffisientene basert på Innherred ikke var vesensforskjellig fra de basert på Ullevål.

Studien viste at epidemiologiske sammenligninger blir mindre valide hvis mer enn ett laboratorium benyttes. Bruk av ett laboratorium som bestreber seg på å opprettholde et stabilt analytisk nivå er den beste strategien. Hvis flere laboratorier benyttes, er kalibrering med felles materiale en metode for å sikre sammenlignbarhet. Det bør i tillegg også gjøres forsøk som dette med tilstrekkelig antall prøver. Ennå bedre vil det være at hvert laboratorium gjør flere bestemmelser på samme serum, gjerne med et intervall på dager eller uker.

\section{REFERANSE}

1. Stensvold I, Urdal P, Thürmer H, Tverdal A, Lund-Larsen PG, Foss OP. High density lipoprotein cholesterol and coronary, cardiovascular and all cause mortality among middle-aged Norwegian men and women. Eur Heart J 1992; 13: 1155-63.

Figur 3. HDL-kolesterol og glukose analysert ved hhv. Klinisk kjemisk avdeling, Ullevål sykehus, og Sentrallaboratoriet, Innherred sykehus.
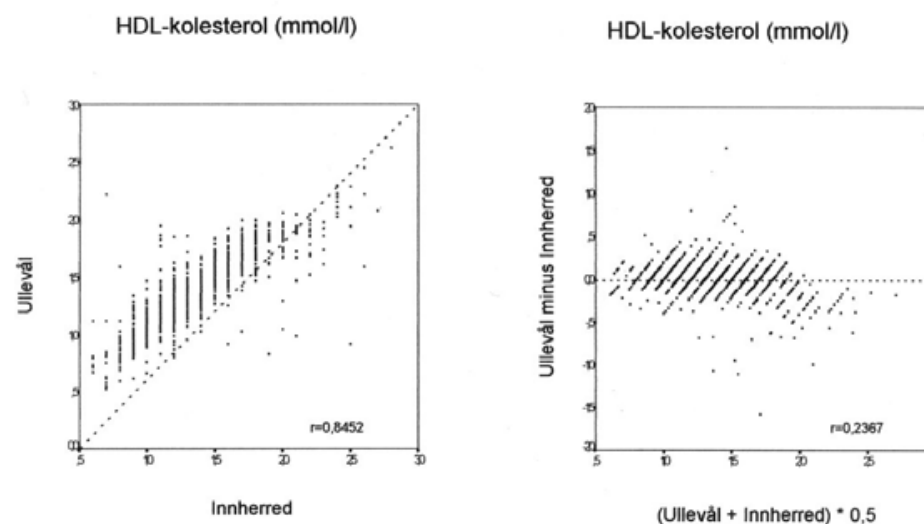

(Ullevål + Innherred) $\cdot 0,5$

Glukose ( $\mathrm{mmol} / \mathrm{)})$

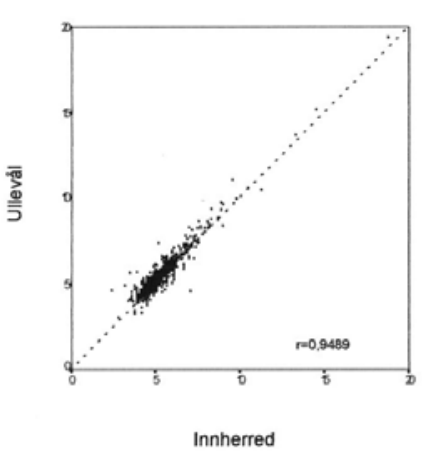

Glukose $(\mathrm{mmol} / \mathrm{l})$

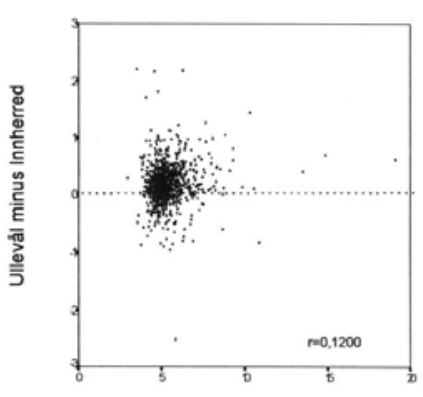

(Ullevål + Innherred) $* 0,5$ 